\title{
Pengembangan Media Transpor untuk Koleksi Sampel Preputium, untuk deteksi Bovine Genital Campylobacteriosis
}

\section{The Development of Transport Media for Prepuce Sample Collection, for Bovine Genital Campylobacteriosis detection}

\author{
Apris Beniawan ${ }^{1}$, Agustin Indrawati ${ }^{2}$, Fachriyan Hasmi Pasaribu ${ }^{2}$ \\ ${ }^{1}$ Badan Karantina Pertanian, Kementerian Pertanian, Jl. Harsono RM. No.3 Ragunan, Jakarta Selatan \\ ${ }^{2}$,Departemen Ilmu Penyakit Hewan dan Kesehatan Masyarakat Veteriner Fakultas Kedokteran Hewan, Institut \\ Pertanian Bogor, Dramaga, Bogor. \\ Email: aprisbeniawan@pertanian.go.id
}

Naskah diterima: 14 Juni 2017, direvisi: 5 Nopember 2019, disetujui: 15 Juli 2020

\begin{abstract}
Campylobacter fetus subsp. Venerealis (Cfv) is bacteria causing contagious genital diseases in cows called Bovine Genital Campylobacteriosis (BGC) or vibriosis. Isolation of $\mathrm{Cfv}$ is difficult, because the bacteria are fragile and need specific nutrients and oxygen (5-10\%). The transport media is very important to maintain $\mathrm{Cfv}$ survival before culturing in laboratory. The aim of this study was to modify a new transport media as an alternative media for Cfv. Modification media capability was compared to Weybridge media, and Phosphate Buffered Saline (PBS). All transport media was contaminated by $\mathrm{Cfv}$ with concentrations of $10^{5}, 10^{4}, 10^{3}, 10^{2}, 10^{1}(\mathrm{CFU} / \mathrm{ml})$, and was stored for $<6,24,48,72$, and 96 hours in each transport medium before culturing on blood agar, all in triplicate. The quality of transport media was analyzed based on bacterial growth on blood agar. PCR test was used as a confirmatory test of growing bacteria cultured on blood agar. Based on culture results, Cfv stored in three transport mediums for $<6$ hours, $\mathrm{Cfv}$ grew on blood agar from all concentration levels provided. Cfv stored for 24, 48, 72 and 96 hours on PBS did not grow, whereas on modification and Weybridge media, the bacteria could grow, and enrichment occurs at all concentration levels given. This study indicated the media modification can be used as an alternative transport medium for Cfv bacteria.
\end{abstract}

Key words: Campylobacter fetus subs. venerealis (Cfv); culture; transport Media

\begin{abstract}
Abstrak
Campylobacterfetus subsp. venerealis (Cfv) adalah bakteripenyebab genital menular pada ternakyang disebut Bovine Genital Campylobacteriosis (BGC) atau vibriosis. Isolasi Cfv ini tidak mudah dilakukan dikarenakan sifat bakteri yang mudah mati, kebutuhan akan nutrisi dan udara yang spesifik (5-10\% $\mathrm{O}_{2}$ ). Pemakaian media transpor menjadi sangat penting dalam menjaga keberlangsungan hidup Cfv sebelum dilakukan pengujian di laboratorium. Tujuan penelitian ini adalah pengembangan media transpor sebagai alternatif media transpor untuk Cfv. Kemampuan media transpor pengembangan ini dibandingkan dengan media Weybridge, dan Phosphate Buffered Saline (PBS). Ketiga media transpor dikontaminasi Cfv dengan konsentrasi bertingkat $10^{5}, 10^{4}, 10^{3}, 10^{2}$, $10^{1}(\mathrm{CFU} / \mathrm{ml})$, dan sampel disimpan berdasarkan masa simpan $<6,24,48,72$, dan 96 jam pada masing-masing media transpor, kemudian dikultur pada media agar darah dengan 3 ulangan. Kualitas ketiga media transpor dianalisa berdasarkan pertumbuhan bakteri pada media agar darah. Uji Polimerase Chain Reaction (PCR) dilakukan sebagai uji konfirmasi hasil kultur dari bakteri yang tumbuh pada media agar darah. Berdasarkan hasil kultur, $\mathrm{Cfv}$ yang disimpan pada ketiga media transpor selama $<6 \mathrm{jam}$, tumbuh pada media agar darah dari semua tingkat kosentrasi yang diberikan, Cfv dengan masa simpan dalam media transpor 24, 48, 72 dan 96 jam pada PBS
\end{abstract}


tidak tumbuh, sedangkan pada media pengembangan dan media Weybridge tumbuh semakin banyak jumlahnya pada semua tingkat konsentrasi yang diberikan. Hasil penelitian ini menunjukkan bahwa media pengembangan dapat digunakan sebagai alternatif media transpor untuk bakteri $\mathrm{Cfv}$.

Kata kunci: Campylobacter fetus subspecies venerealis (Cfv); kultur bakteri; media transpor

\section{Pendahuluan}

Campylobacter fetus subsp. venerealis (Cfv) adalah bakteri penyebab Bovine Genital Campylobacteriosis (BGC). Penyakit ini dahulu disebut vibriosis, dengan gejala yang ditimbulkan diantaranyainfertilitas temporer pada ternak betina, mortalitas embrio stadium awal, siklus estrus tidak teratur, konsepsi tertunda dan terkadang abortus. Hewan yang sembuh dari infeksi Cfv, siklus estrus akan kembali normal dalam beberapa bulan, tetapi akan mengalami penurunan angka kebuntingan dan periode kelahiran yang lebih panjang (Monke et al., 2002). Pada hewan jantan biasanya tidak menunjukkan gejala klinis, tetapi menjadi carrier dan menginfeksi hewan betina. Inseminasi Buatan (IB), vaksinasi dan pemisahan kelompok yang terinfeksi dengan yang tidak terinfeksi merupakan cara yang efektif dalam pengendalian BGC (Eaglesome and Garcia, 1992).

Berdasarkan Kepmentan No. 3238/Kpts/ PD.630/9/2009, BGC termasuk Hama dan Penyakit Hewan Karantina Golongan I (Kementan RI, 2009). Penelitian BGC di Indonesia dilakukan oleh peneliti Balai Besar Peneilitian Veteriner (BBLITVET) pada tahun 1998, oleh Hardjoutomo pada 9 Provinsi di Indonesia dengan hasil negatif Cfv, dan sampai saat ini belum ada publikasi lebih lanjut tentang BGC di Indonesia.

Indonesia sampai sekarang ini melakukan importasi sapi hidup dari Australia yang merupakan negara belum bebas dari BGC (Koya, 2016). Ketergantungan impor sapi hidup Indonesia dari Australia jumlahnya sangat banyak, mencapai rata-rata 800 ribu ekor per tahunnya untuk memenuhi kebutuhan protenin hewani masyarakat, oleh karena itu, deteksi Cfv harus mulai diterapkan, untuk mencegah penyebaran BGC pada sapi di Indonesia.

Identifikasi BGC pada hewan masih sulit, karena tidak adanya tanda-tanda klinis penyakit, bersifat tersembunyi, membahayakan karena sering tidak diketahui keberadaannya dalam peternakan, dan menyebabkan kerugian produksi dalam jangka panjang (Hum, 2007). Isolasi bakteri Cfv tidak mudah dilakukan dikarenakan bakteri mudah mati, membutuhkan nutrisi dan udara yang spesifik. Spesimen yang akan digunakan dalam proses pengujian seperti kultur bakteri memerlukan penanganan yang cermat dan cepat karena kelangsungan hidup Cfv di luar tempat alaminya terbatas dan bersifat mikroaerofilik. Keberadaan kontaminan bakteri lain dapat tumbuh lebih cepat dalam sampel, seperti Pseudomonas spp. dan Proteus spp, membuat sulit dalam mendeteksi keberadaan Cfv (Monke et al., 2002). Media transpor sangat penting dalam menjaga keberlangsungan hidup Cfv dalam sampel sebelum dilakukan kultur sebagai standar baku pengujian. Beberapa media transpor untuk Cfv telah dikembangkan, diantaranya: Clark's, Landers's, dan Cary-Blair's, serta Weybridge sebagai media transpor yang direkomendasikan OIE (2012). Media transpor komersial untuk $\mathrm{Cfv}$ relatif mahal serta masih sulit didapatkan. Berdasarkan pertimbangan tersebut, diperlukan pengembangan media transpor untuk $\mathrm{Cfv}$ yang lebih mudah dipersiapkan, murah dan berkualitas untuk koleksi sampel sebelum pengujian. Penelitian ini bertujuan untuk mengembangkan media transpor yang berkualitas, murah dan mudah untuk mendukung pengujian $\mathrm{Cfv}$.

\section{Materi Dan Metode}

\section{Desain Penelitian}

Isolat bakteri $\mathrm{Cfv}$ referensi diuji terlebih dahulu menggunakan metode kultur dan Polymerase Chain Reaction (PCR) sebagai uji konfirmasi. Bakteri hasil kultur kemudian dilakukan pengukuran konsentrasi dengan spektrofotometri untuk mendapatkan konsentrasi awal bakteri $10^{8} \mathrm{CFU} / \mathrm{ml}$ (Standar kekeruhan $M c$ Farland, 0.5). Bakteri Cfv dari hasil pengukuran konsentrasi awal dilakukan pengenceran bertingkat untuk menghasilkan konsentrasi bakteri Cfv dengan konsentrasi $10^{5}, 10^{4}, 10^{3}, 10^{2}$, 
$10^{1}$ (CFU / ml). Bakteri Cfv dari masing masing konsentrasi dicampur dan disimpan dalam media transpor. Media transpor yang sudah bercampur bakteri Cfv disimpan dalam suhu ruang $\left(25-27^{\circ} \mathrm{C}\right)$ selama penelitian. Sampel bakteri Cfv dari masingmasing media transpor dikultur pada media agar darah sesuai masa simpan bakteri dalam media transpor $(<6,24,48,72$ dan 96 jam $)$ di masingmasing konsentrasi bakteri yang telah ditentukan. Kultur dilakukan ulangan sebanyak 3 kali dari semua sampel bakteri Cfv yang diujikan. Hasil kultur dilakukan pengamatan secara makroskopis dan penghitungan jumlah koloni bakteri Cfv yang tumbuh pada media agar darah. Bakteri yang tumbuh pada media agar darah sebagai hasil kultur dilakukan uji konfirmasi menggunakan PCR.

\section{Isolat Bakteri Referensi}

Isolat bakteri referensi berasal dari koleksi BBLITVET, yaitu Campylobacter fetus subspecies venerealis (Kode No. C5) dan Campylobacter fetus subs. fetus (Kode No. C2) sebagai kontrol pembanding.

\section{Ekstraksi DNA}

Metode ekstraksi DNA dilakukan dengan perebusan, dengan mengambil 2-3 ose bakteri hasil kultur dan dicampurkan dalam larutan PBS, kemudian suspense bakteri disentrifus 12.000 rpm selama 5 menit, dan dibuang supernatannya. Endapan bakteri kemudian ditambahkan nuclease free water dan kembali disentrifus $12.000 \mathrm{rpm}$ selama 5 menit, dan dibuang supernatannya. Endapan ditambahkan kembali nuclease free water $1 \mathrm{ml}$ dan dididihkan dalam waterbath suhu $95^{\circ} \mathrm{C}$ selama 10 menit, kemudian disentrifus $10.000 \mathrm{rpm}$ selama 1 menit. Supernatan diambil sebagai DNA template.

\section{Uji Polimerase Chain Reaction (PCR)}

Uji multiplex PCR dilakukan dengan reaksi yang terdiri dari $10 \mu \mathrm{l}$ Kapa ReadyMix, $0.6 \mu \mathrm{l}$ $(10 \mu \mathrm{M})$ untuk masing-masing primer MG3F dan MG4R dan $0.5 \mu \mathrm{l}(10 \mu \mathrm{M})$ untuk masing-masing primer VenSF dan VenSR dan nuclease free water hingga mencapai volume $18 \mu \mathrm{l}$, dan $2 \mu \mathrm{l}$ DNA template ditambahkan dengan total keseluruhan $20 \mu 1$. Kontrol positif, negatif dan non template control (NTC) disertakan dalam setiap amplifikasi.
Program PCR yang digunakan adalah 1 siklus pada $95^{\circ} \mathrm{C}$ selama 3 menit untuk denaturasi awal, dilanjutkan dengan 35 siklus pada $95^{\circ} \mathrm{C}$ selama 15 detik untuk denaturasi, $54{ }^{\circ} \mathrm{C}$ selama 15 detik untuk annealing, dan $72{ }^{\circ} \mathrm{C}$ selama 30 detik untuk ekstensi, kemudian dilanjutkan dengan 1 siklus pada $72{ }^{\circ} \mathrm{C}$ selama 5 menit untuk ekstensi akhir. Produk amplifikasi kemudian dianalisis dengan elektroforesis. Pita spesifik Cff akan terbaca pada $764 \mathrm{pb}$, sedangkan $C f$ terbaca pada $764 \mathrm{pb}$ dan 142 pb (Hum et al., 2009). Produk PCR diseparasi menggunakan $2 \%$ agarose yang telah ditambahkan ethidium bromide $0.5 \mu \mathrm{g} / \mathrm{ml}$ pada tegangan $120 \mathrm{~V}$ selama 1 jam menggunakan marker 1000 bp DNA ladder. Hasil elektroforesis selanjutnya dilihat menggunakan Gel-Documentation.

Primer yang digunakan dalam penelitian ini adalah primer MG3F dan MG4R yang yang spesifik terhadap dua subspesies C. fetus ; primer VenSF dan VenSR yang spesifik terhadap C. fetus subsp. venerealis. Sekuens oligonukleotida primer yang digunakan dalam pengujian dapat dilihat pada Tabel 1 .

Tabel 1. Sekuen primer untuk Multiplex PCR (Hum et al., 2009)

\begin{tabular}{ccc}
\hline Primer & Sekuen & $\begin{array}{r}\text { Ukuran } \\
\text { Produk }\end{array}$ \\
\hline VenSF & 5'-CTT AGC AGT TTG CGA TAT TGC & 142 bp \\
CAT T-3' & \\
VenSR & 5'-GCT TTT GAG ATA ACA ATA AGA & GCT T-3' \\
MG3F & 5'-GGT AGC CGC AGC TGC TAA & G64 bp \\
MG4R & 5'-TAG CTA CAA TAA CGA CAA & \\
\hline
\end{tabular}

\section{Media Transpor}

Media transpor yang dikembangkan dibuat dengan menggunakan suspensi dari $10 \mathrm{~g} / \mathrm{lt}$ protease peptone, $2 \mathrm{~g} / \mathrm{lt}$ glucose, $5 \mathrm{~g} / \mathrm{lt} \mathrm{NaCl}$, ke dalam aquadestt rata sampai dengan volume total $1 \mathrm{~L}$ dan dilakukan penyesuaian $\mathrm{pH}$ 7.2. Suspensi tersebut selanjutnya ditambahkan $50 \mathrm{gr} / \mathrm{L}$ daging sapi cincang tanpa lemak, dan diautoklaf pada suhu $121{ }^{\circ} \mathrm{C}$ selama 15 menit untuk sterilisasi. Setelah media dingin, ditambahkan suplemen yang terdiri dari $40 \mathrm{mg}$ Vancomycin, $20 \mathrm{mg}$ Trimetropim, 10.000 IU Polymyxin B Shulphate, yang dilarutan dalam aquadest tilata dan dilakukan filter secara steril ke dalam media menggunakan membran 
filter 0.22 um (Milipore ${ }^{\circledR}$ ). Larutan disimpan pada suhu $4-8{ }^{\circ} \mathrm{C}$ sampai saat penggunaan.

Media Weybridge dibuat dengan menambahkan Mueller-Hinton broth dan charcoal bacteriologis ke dalam $900 \mathrm{ml}$ aquadestt dan di autoklaf, setelah media dasar dingin, ditambahkan darah kuda, dan ditambahkan vancomysin, polymixin $B$ dan Polymyxin B Shulphate yang dilarutan dalam aquadest dan filter secara steril ke dalam media dasar menggunakan membrane filter 0.22 um (Milipore $\left.{ }^{\circledR}\right)$. Larutan ditambahkan dengan Sodium Pyruvate, Sodium Metabisulphite dan Ferrous Sulphate secara steril, dicampur (diaduk), kemudian disimpan pada suhu $4-8{ }^{\circ} \mathrm{C}$ sampai saat penggunaan.

Phosphate Buffered Saline (PBS) dalam penelitian ini digunakan sebagai media transpor pembanding dengan perlakuan dan desain penelitian yang sama. Phosphate Buffered Saline adalah larutan garam berbasis air yang mengandung natrium klorida, natrium fosfat, dan dalam beberapa formulasi, kalium klorida dan kalium fosfat.

\section{Media Agar Darah}

Media kultur bakteri pada penelitian ini menggunakan media agar darah. Pembuatan media agar dilakukan dengan menambahkan Columbia blood agar base $(39 \mathrm{~g} / \mathrm{L})$, selanjutnya diautoklaf pada suhu $121^{\circ} \mathrm{C}$ selama 15 menit dan didinginkan dalam waterbath yang diatur pada suhu $50{ }^{\circ} \mathrm{C}$. Setelah larutan hangat $\left(50{ }^{\circ} \mathrm{C}\right)$, ditambahkan 100 $\mathrm{ml}$ darah domba defibrinasi dan diaduk perlahan secara merata. Larutan secara perlahan dituang sebanyak $\pm 18 \mathrm{ml}$ ke dalam cawan petri ukuran 15 x $90 \mathrm{~mm}$ dan dibiarkan membeku. Media disimpan pada suhu $4-8{ }^{\circ} \mathrm{C}$ dalam wadah plastik tertutup maksimum hingga 3 minggu.

\section{Kultur}

Kulturbakteridilakukan denganmenggunakan tingkat konsentrasi bakteri yang berbeda dan disimpan dalam media transpor dengan waktu yang berbeda $(<6 \mathrm{~d} / \mathrm{H})$, diambil $100 \mathrm{ul}$ sampel dari media media transpor, kemudian diteteskan pada satu sisi tepi agar darah, dan diratakan, digoreskan di semua sisi tanpa menyentuhan ose ke ujung akhir setiap goresan. Agar darah yang sudah digores dimasukkan ke dalam Aanaerobic
Jar yang di dalamnya diberi CampyGen untuk mendapatkan kondisi mikroaerofilik. Anaerobic Jar dimasukkan ke dalam inkubator, diinkubasi selama 3 hari pada suhu $37^{\circ} \mathrm{C}$.

\section{Analisa Makroskopis dan Statistika}

Setelah masa inkubasi, koloni bakteri hasil kultur yang tumbuh pada media agar darah dilakukan pengamatan secara makroskopis dan penghitungan koloni bakteri. Data hasil hitung koloni bakteri $\mathrm{Cfv}$ dilakukan analisa statistika menggunakan uji Kruskal-Wallis.

\section{Hasil Dan Pembahasan}

\section{Isolat Bakteri Referensi}

Hasil kultur isolat bakteri referensi dari kedua isolat (Cff dan Cff) yang ditumbuhkan, terlihat tumbuh pada media agar darah, sebagaimana terlihat pada Gambar 1. Gambaran makroskopis koloni bakteri Cfv dan Cff yang tumbuh bentuknya seragam, terlihat halus, berwarna abu-abu merah muda, mengkilap, koloni berukuran kecil dan tidak ada perubahan warna pada media agar darah. Menurut Ng et al. (1985) bakteri Cfv hasil kultur biasanya menunjukkan koloni yang berbentuk bulat atau coccus bening (mengkilap). Koloni bakteri Cfv dan Cff berukuran kecil yaitu 1-3 mm, terlihat halus, berwarna abuabu merah muda, mengkilap dan bersifat non haemolytic (OIE, 2012).

Hasil PCR menunjukkan bahwa isolat bakteri referensi No. C5 dan C2 yang tumbuh pada media agar darah adalah bakteri Cfv dan Cff, sesuai dengan kontrol yang terlihat pada Gambar 2. Uji PCR menggunakan seperangkat primer (MG3F dan MG4R) untuk identifikasi strain fetus yang teridentifikasi sebagai 762 bp (Muller et al., 2003), dan primer kedua (VenSF dan VenSR) yang spesifik untuk fetus subs. venerealis (142 bp) dalam format multiplex PCR (Hum et al., 2009).
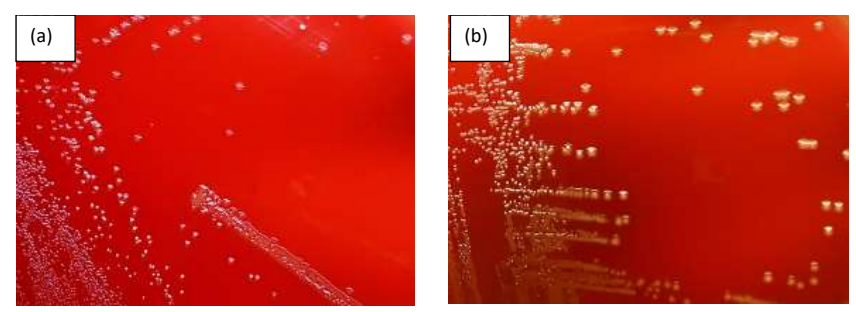

Gambar 1. Hasil Kultur Isolat (a) Cfv/C5 dan (b) Cff (C2) 


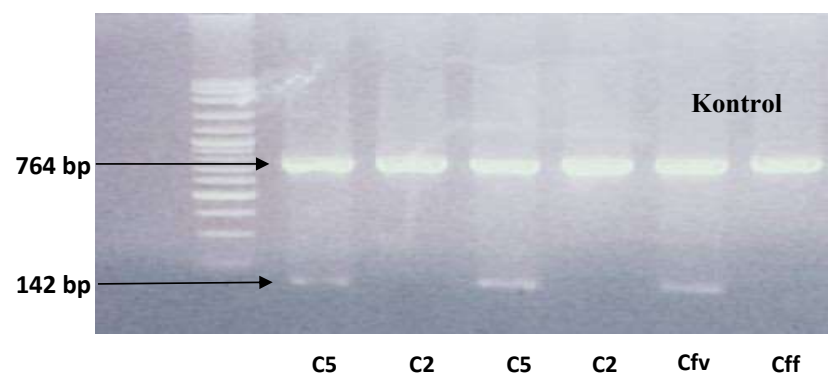

Gambar 2. PCR Hasil Kultur Isolat Referensi (Cfv dan Cff) yang tumbuh pada media agar darah.

\section{Hasil Kultur Bakteri Cfv dari Media Transpor}

Kultur bakteri pada media agar darah dilakukan sesuai masa simpan dalam media transpor selama $<6,24,48,72$ dan 96 jam dari masing-masing konsentrasi bakteri. Gambaran media traspor dalam penelitian ini terlihat pada Gambar 3. Media transpor yang dikembangkan terlihat berwarna sedikit bening kekuningan dikarenakan adanya daging sapi yang terurai sebagai kaldu. Media Weybridge terlihat berwana hitam dan sedikit merah kecoklatan karena adanya charcoal dan darah domba sebagai materi penyusun media. Phosphate Buffered Saline sebagaimana umumnya, dalam penelitian ini terliha berwarna bening.

Penelitian ini menggunakan konsentrasi bakteri Cfv bertingkat yaitu $10^{5}, 10^{4}, 10^{3}, 10^{2}, 10^{1}$ $(\mathrm{CFU} / \mathrm{ml})$, dan disimpan dalam masing-masing media transpor, sesuai dengan tingkat konsentrasi. Menurut Lander (1990), karakteristik sampel yang mempengaruhi keberhasilan kultur adalah konsentrasi awal koloni Campylobacter yang ada
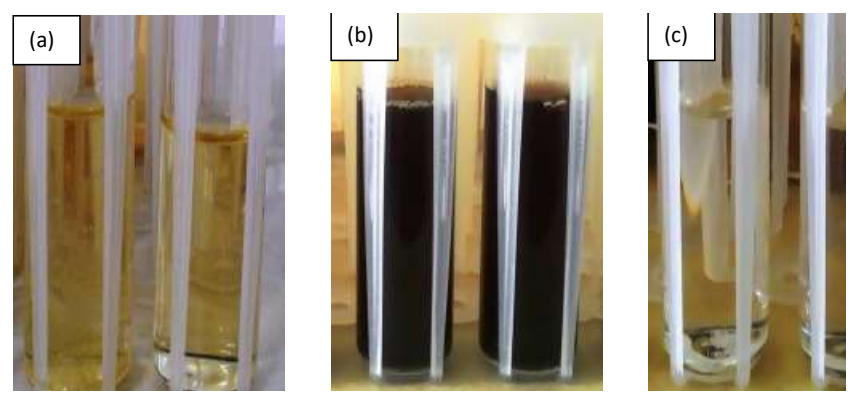

Gambar 3. Media transport (a) Media Pengembangan; (b) Weybridge; dan (c) PBS.

dalam sampel, dan waktu dari inokulasi sampai inkubasi dalam media transpor. Konsentrasi bakteri Cfv dalam preputial dapat bervariasi antara $10^{2}-10^{5} \mathrm{CFU} / \mathrm{ml}$ (Clark, 1971).

Koloni bakteri yang tumbuh pada media agar darah dilakukan pengamatan makroskopis dan dilakukan penghitungan jumlah koloni. Gambaran makroskopis koloni bakteri Cfv dan Cff yang tumbuh pada media agar darah dalam penelitian ini tampak seragam, terlihat halus, berwarna abuabu merah muda, mengkilap, berbentuk bulat, berukuran kecil dan darah dalam media agar tidak lisis yang menggambarkan bahwa bakteri yang tumbuh bersifat non haemolytic (Gambar 4).
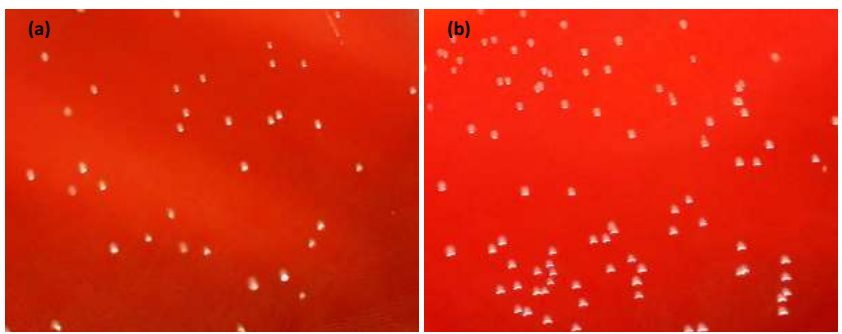

Gambar 4. Hasil Kultur sampel H2 $\left(10^{2} \quad \mathrm{cfu} / \mathrm{ml}\right) ; \quad$ (a) Pengembangan; (b) Weybridge

Tabel 2. Jumlah Koloni Bakteri Cfv

\begin{tabular}{|c|c|c|c|c|c|c|}
\hline \multirow{2}{*}{ Media transpor } & \multirow{2}{*}{$\mathrm{Cfu} / \mathrm{ml}$} & \multicolumn{5}{|c|}{ Jumlah Bakteri ( x10) } \\
\hline & & H1 & $\mathrm{H} 2$ & $\mathrm{H} 3$ & $\mathrm{H} 4$ & H5 \\
\hline \multirow{5}{*}{ Pengembangan } & $10^{1}$ & 5 & 12 & 41 & $>300$ & $>300$ \\
\hline & $10^{2}$ & 37 & 70 & 134 & $>300$ & $>300$ \\
\hline & $10^{3}$ & 218 & 218 & $>300$ & $>300$ & $>300$ \\
\hline & $10^{4}$ & $>300$ & $>300$ & $>300$ & $>300$ & $>300$ \\
\hline & $10^{5}$ & $>300$ & $>300$ & $>300$ & $>300$ & $>300$ \\
\hline \multirow[t]{5}{*}{ Weybridge } & $10^{1}$ & 6 & 11 & 145 & $>300$ & $>300$ \\
\hline & $10^{2}$ & 21 & 167 & $>300$ & $>300$ & $>300$ \\
\hline & $10^{3}$ & 119 & $>300$ & $>300$ & $>300$ & $>300$ \\
\hline & $10^{4}$ & $>300$ & $>300$ & $>300$ & $>300$ & $>300$ \\
\hline & $10^{5}$ & $>300$ & $>300$ & $>300$ & $>300$ & $>300$ \\
\hline
\end{tabular}


Jumlah hasil penghitungan bakteri Cfv yang tumbuh pada media agar darah terlihat pada Tabel 2. Koloni yang tidak memungkinkan untuk dihitung, terhitung $>300 \mathrm{koloni} /$ cawan.

Hasil kultur dari sampel dengan masa simpan kurang dari 6 jam $(\mathrm{H} 1)$ di media transpor yang dikembangkan, Weybridge dan PBS, bakteri Cfv tumbuh pada semua media agar darah pada semua tingkat konsentrasi bakteri $10^{5}, 10^{4}, 10^{3}, 10^{2}, 10^{1}$ (CFU/ml). Hasil pengamatan pada masa simpan 24, 48, 72 dan 96 jam dalam media pengembangan dan Weybridge terjadi peningkatan jumlah koloni bakeri yang tumbuh di semua tingkat konsentrasi, sedangkan pada sampel yang disimpan dalam PBS tidak ada pertumbuhan bakteri disemua tingkat konsentrasi. Hasil ini menunjukkan bahwa ketiga media dapat digunakan sebagai media transpor untuk banteri $\mathrm{Cfv}$ apabila masa simpan bakteri kurang dari 6 jam dalam media transpor. Namun dengan masa simpan lebih dari 24, 48, 72 dan 97 jam hanya media pengembangan dan media Weybridge yang bersifat enrichment untuk bakteri Cfv, sehingga dapat tumbuh pada media kultur (Tabel. 2)

Phosphate Buffered Saline (PBS) merupakan media cair yang biasa digunakan untuk pengambilan sampel Cfv apabila tidak memerlukan transportasi yang lama, namun untuk sampel yang memerlukan perjalanan lebih dari 6-8 jam sebelum pengujian (kultur), diperlukan Transport Enrichment Medium (OIE, 2012). Phosphate Buffered Saline sebagai buffer membantu bakteri dalam mempertahankan konsistensi $\mathrm{pH}$, namun kandungan PBS tidak memenuhi kebutuhan nutrisi dari bakteri $\mathrm{Cfv}$ untuk tumbuh dan mempertahankan hidup dalam waktu yang lebih lama. Bakteri Cfv sama dengan mikroorganisme lainnya, memerlukan suplai nutrisi sebagai sumber energi dan pertumbuhannya. Unsur-unsur dasar tersebut adalah: karbon, nitrogen, hidrogen, oksigen, sulfur, fosfor, zat besi dan sejumlah komponen lainnya. Tidak adanya atau kekurangan sumber-sumber nutrisi ini dapat mempengaruhi pertumbuhan mikroba hingga pada akhirnya dapat menyebabkan kematian. Menurut Hum et al. (2009) Camplylobacter fetus subsp. venerealis (Cfv) adalah parasit obligat yang menular melalui kelamin pada sapi, beradaptasi pada permukaan mukosa preputial dan rongga vagina, non spora, bersifat rentan karena hanya mampu bertahan 6 jam pada kondisi atmosfer normal.

Media Weybridge merupakan media transpor yang direkomendasikan oleh OIE (2012), dikembangkan oleh Lander (1990), dengan formula terdiri dari mueller hinton broth terbuat dari beef infusion (ekstrak daging sapi), acid casein peptone, dan Corn Starch. Ekstrak daging sapi dan acid casein peptone sebagai sumber nitrogen, vitamin, mineral dan asam amino yang penting untuk pertumbuhan bakteri Cfv. Corn starch (tepung pati) merupakan faktor pendukung pertumbuhan bakteri sebagai sumber energi dan berfungsi untuk menyerap racun yang dikeluarkan bakteri, sehingga tidak mengganggu pertumbuhan bakteri. Charcoal sering digunakan sebagai sumber carbon, komponen media transporasi, penyimpanan dan propagasi mikroorganisme, terutama untuk bakteri mudah mati (Lander, 1990). Darah domba adalah sumber nutrisi kaya protein dan tinggi zat besi sebagai faktor pertumbuhan sel bakteri. Suplemen yang terdiri dari Sodium Pyruvate, Sodium Metabisulphite dan Ferrous Sulphate (FBP) dapat meningkatkan sifat aerotoleran bakteri Campylobacter fetus (George et al., 1978). Penambahan kombinasi antibakteri Vankomysin, Trimetoprim dan Polymyxin sebagai medium selektif, untuk mematikan bakteri kontaminan lainnya (Skirrow, 1994).

Media transpor yang dikembangkan dibuat dari daging sapi, protease peptone, glucose, $\mathrm{NaCl}$ sebagai penghambat pertumbuhan bakteri lain yang toleran terhadap garam, air (aquadestt) sebagai pelarut dan antibiotik spesifik (vancomysin, polymixin $B$ dan cycloheximide) sebagai penghambat pertumbuhan bakteri kontaminan. Daging sapi sering digunakan sebagai bahan untuk media pertumbuhan bakteri, dikarenakan memiliki banyak nutrisi yang dibutuhkan bakteri untuk tumbuh. Kandungan danging sapi terdiri dari kalori, protein, lemak, karbohidrat, kalsium, fosfor, zat besi, selenium, seng, zink, vitamin B kompleks, omega 3 dan zat lainnya. Protease peptone mengandung nitrogen, amino nitrogen dan sodium klorida yang dibutuhkan oleh bakteri untuk pertumbuhan.

Hasil uji statistik terhadap ketiga media transpor menunjukkan bahwa tidak ada perbedaan signifikan pada perlakuan masa simpan $<6$ jam, 
Tabel 3. Uji Kruskal Wallis untuk media pengenbangan, Weybridge dan PBS

\begin{tabular}{cccccc}
\hline \multirow{2}{*}{ Masa simpan } & $\begin{array}{c}\text { Pengenceran }(\mathrm{Cfu} / \\
\mathrm{ml})\end{array}$ & Pengembangan & $\begin{array}{c}\text { Median } \\
\text { Weybridge's }\end{array}$ & PBS & Nilai P \\
\hline H1 & $10^{1}$ & 5.000 & 6.000 & 4.000 & $\mathbf{0 . 6 5 8}$ \\
$(<6$ jam $)$ & $10^{2}$ & 33.00 & 35.00 & 39.00 & $\mathbf{0 . 6 4 6}$ \\
& $10^{3}$ & 218.0 & 300.0 & 156.0 & $\mathbf{0 . 4 8 8}$ \\
H2 & $10^{1}$ & $1.20000 \mathrm{E}+01$ & $1.50000 \mathrm{E}+01$ & 0.000000000 & $\mathbf{0 . 0 4 5}$ \\
$(24$ jam $)$ & $10^{2}$ & $7.00000 \mathrm{E}+01$ & $1.49000 \mathrm{E}+02$ & 0.000000000 & $\mathbf{0 . 0 2 4}$ \\
& $10^{3}$ & $2.48000 \mathrm{E}+02$ & $3.00000 \mathrm{E}+02$ & 0.000000000 & $\mathbf{0 . 0 2 1}$ \\
H3 & $10^{1}$ & $4.90000 \mathrm{E}+01$ & $1.07000 \mathrm{E}+02$ & 0.000000000 & $\mathbf{0 . 0 2 8}$ \\
\hline
\end{tabular}

Keterangan: Nilai $\mathrm{P}<0.5=$ ada perbedaan signifikan

namun ada perbedaan signifikan pada masa simpan 24, 48, 72 dan 96 jam (Tabel 3), dimana tidak ada pertumbuhan bakteri pada media agar darah dari sampel asal PBS.

Uji statistik media pengembangan dibandingkan dengan media Weybridge didapatkan tidak adanya perbedaan signifikan dari masa simpan $<6$ jam (H1) di semua tingkat konsentrasi. Hasil uji statistik dari masa simpan 24 (H2) konsentrasi $10^{1}, 10^{2}$ tidak berbeda signifikan, namun ada perbedaan signifikan $(\mathrm{P}=0.037)$ pada konsentrasi $10^{3}$, begitu juga pada masa simpan 48 jam (H3) pada media dengan konsentrasi $10^{1}$ tidak berbeda signifikan, namun ada perbedaan signifikan $(\mathrm{P}=0.037)$ pada konsentrasi $10^{2}$ (Tabel 4). Hal ini menunjukkan bahwa bakteri Cfv dapat tumbuh dan berkembang (enrichment) dalam media pengembangan, namun masih lebih sedikit hasilnya dibandingkan dengan media Weybridge.

Hasil penelitian ini menunjukkan bahwan media Weybridge mengandung nutrisi-nutrisi yang dibutuhkan untuk pertumbuhan bakteri
Cfv. Media Weybridge memiliki sumber zat besi yang lebih dikarenakan adanya adanya tambahan suplemen FBP (meningkatkan sifat aerotoleran untuk bakteri Cfv yang bersifat mikroaerofilik), darah domba, mueller hinton dan Ferrous Sulfat sebagai sumber zat besi. Media pengembangan mendapatkan zat besi dari daging sapi, dimana terdapat $14-15 \%$ zat besi dalam daging sapi. Zat besi merupakan nutrisi penting bagi semua organisme hidup, karena merupakan kofaktor dari banyak enzim, dan berperan penting dalam reaksi transpor elektron dan reaksi redoks, sehingga terbatasnya ketersediaan zat besi menghambat pertumbuhan bakteri. (van Vliet et al., 2002).

Hasil multiplex PCR sebagai uji konfirmasi menunjukkan bahwa dari semua bakteri yang tumbuh di semua tingkat perlakuan (konsentrasi) yang diberikan adalah bakteri Cfv (Gambar. 5).

Media pengembangan memiliki komponen yang cukup untuk pertumbuhan bakteri $\mathrm{Cfv}$, dimana bahan-bahan yang digunakan lebih murah dan mudah didapat di Indonesia. Proses

Tabel 4. Hasil Uji Kruskal Wallis media pengembangan dan Weybridge

\begin{tabular}{lcccc}
\hline \multirow{2}{*}{ Masa simpan } & \multirow{2}{*}{ Pengenceran $(\mathrm{Cfu} / \mathrm{ml})$} & \multicolumn{2}{c}{ Median } & \multirow{2}{*}{ Nilai P } \\
& $10^{1}$ & 5.000 & 6.000 & $\mathbf{0 . 3 6 9}$ \\
H1 (<6 jam) & $10^{2}$ & 33.00 & 35.00 & $\mathbf{0 . 8 2 7}$ \\
& $10^{3}$ & 218.0 & 300.0 & $\mathbf{0 . 5 0 7}$ \\
\hline \multirow{2}{*}{ H2 (24 jam) } & $10^{1}$ & 12.00 & 15.00 & $\mathbf{0 . 2 6 8}$ \\
& $10^{2}$ & 70.00 & 149.00 & $\mathbf{0 . 0 5 0}$ \\
\hline \multirow{2}{*}{ H3 (48 jam) } & $10^{3}$ & 248.00 & 300.00 & $\mathbf{0 . 0 3 7}$ \\
& $10^{1}$ & 49.00 & 107.00 & $\mathbf{0 . 0 7 7}$ \\
\hline
\end{tabular}




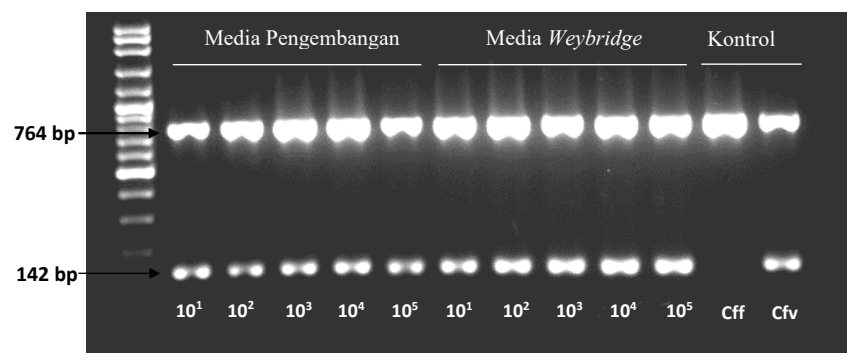

Gambar 5. Hasil Uji multiplex PCR Cfv yang tumbuh pada media pengembangan dan media Weybridge

pembuatan media pengembangan lebih sederhana dan lebih mudah, sehingga waktunya lebih cepat.

\section{Kesimpulan}

Media pengembangan bersifat enrichment (pengkayaan), dapat digunakan sebagai alternatif media transpor untuk koleksi sampel untuk deteksi Campylobacter fetus subspecies venerealis.

\section{Ucapan Terimakasih}

Terimakasih penulis ucapkan kepada Program Studi Mikrobiologi Medik, Sekolah Pasca Sarjana IPB. Penulis juga menyampaikan Terimakasih kepada Badan Karantina Pertanian atas beasiswa S2 yang telah diberikan. Semoga karya ilmiah ini bermanfaat.

\section{Daftar Pustaka}

Clark, B.L. (1971). Review of Bovine Vibriosis. Australian Vet J. 47:103-107.

Eaglesome, M.D. and Garcia, M.M. (1992). Microbial agents associated with bovine genital tract infections and semen. Part I. Brucella abortus, Leptospira, Campylobacter fetus and Tritrichomonas foetus. Vet Bull. 62(8):743-775.

George, H.A., Hoffman, P.S., Smibert, R.M. and Krieg, N.R. (1978). Improved media for growth and aerotolerance of Campylobacter fetus. J Clin Microbiol 8(1): 36-41.

Hardjoutomo, S. (1998). Tinjauan tentang Vibriosis Sapi di Indonesia. Wartazoa 7 (1); $10-14$.

Hum, S. (2007). Vibriosis of Cattle. New South Wales Department of Primary Industries.
Australia. Primefact 451.

Hum, S., Hornitzky, M., Berg, T. (2009). Bovine Genital Campylobacteriosis. Australia and New Zealand Standard Diagnostic Procedures, SCAHLS, ed. (Department of Agriculture, Fisheries and Forestry).

[Kementan RI] Kementerian Pertanian Republik Indonesia. (2009). Keputusan Menteri Pertanian Nomor 3238/Kpts/Pd.630/9/2009: Tentang Penggolongan Jenis-Jenis Hama Penyakit Hewan Karantina, Penggolongan dan Klasifikasi Media Pembawa. Jakarta (ID): Kementerian Pertanian Republik Indonesia.

Koya, A. (2016). Bovine Genital Campylobacteriosis: Isolation, identification and virulence profiling of Campylobacter fetus subsp. venerealis in a small animal model. Thesis for the degree of Doctor of Philosophy. School of Veterinary Science. University of Queensland.

Lander, K.P. (1990). The application of a transport and enrichment medium to the diagnosis of Campylobacter fetus infections in bulls. British Vet J. 146:334-340.

Monke, H.J., Love, B.C., Wittum, T.E., Monke, D.R. and Byrum, B.A. (2002). Effect of transport enrichment medium, transport time, and growth medium on the detection of Campylobacter fetus subsp. venerealis. $J$ Vet Diagn Investigation. 14:35-39.

Muller, W., Hotzel, H. and Schulze, F. (2003). Identification and differentiation of Campylobacter fetus subspecies by PCR. Dtsch Tierarztl Wochenschr 110(2): 55-59.

Ng, L., Sherburne, R., Taylor, D.E. and Stiles, M.E. (1985). Morphological forms and viability of Campylobacter species studied by electron microscopy. $J$ Bacteriol. 164(1):338-343.

[OIE] World Organization for Animal Health. (2012). Manual of Diagnostic Tests and Vaccines for Terrestrial Animals. Terrestrial Manual 2012 Seventh Edition Volume 2. https://www.oie.int/doc/ged/D12009.PDF. 
Skirrow, M.B. (1994). Diseases due to Campylobacter, Helicobacter and related bacteria. J Comparative Pathol. III:113149. van Vliet, A.H.M., Ketley, J.M., Park, S.F. and Penn, C.W. (2002). The role of iron in Campylobacter gene regulation, metabolism and oxidative stress defence. FEMS Microbiology Reviews 26 (2002): 173-186. 